\title{
REKOMENDASI PENINGKATAN PEMANFAATAN POSYANDU OLEH IBU BALITA BERDASARKAN ANALISIS TOTAL CUSTOMER SACRIFICES
}

\section{RECOMMENDATIONS FOR POSYANDU UTILIZATION IMPROVEMENT AMONG MOTHERS OF UNDER- FIVE CHILDREN BASED ON TOTAL CUSTOMER SACRIFICES ANALYSIS}

Nurul Hidayatul Mukaromah, Ratna Dwi Wulandari

Fakultas Kesehatan Masyarakat, Universitas Airlangga, Surabaya

Email: nurul-h-m-fkm11@unair.ac.id

\begin{abstract}
The coverage of under-five children weighed is an indicator of community participation in Posyandu. During 2012 until 2014, Puskesmas Kenjeran had not reached the target of this indicator. The objective of this study is to arrange recommendations for Posyandu utilization improvement based on total customer sacrifice analysis. This was a quantitative analytical study with observational approach and cross sectional design. The sampling was calculated by using multistage random sampling method. The interviews through instrument were conducted to 112 respondents to obtain information on Posyandu utilization and respondents sacrifice required to utilize Posyandu. The results showed that respondents thought time was the greatest sacrifice among monetary, energy, and psychological sacrifices. Spearman correlation test on any sacrifice required showed significant correlation $(p<0.05)$, except for monetary sacrifice. This study concluded that even total customer sacrifices was very small, but the huge expense of time spent still made respondents to be less likely to utilize Posyandu. Therefore, efforts are needed to reduce the magnitude of the sacrifice required by community utilizing Posyandu in Puskesmas Kenjeran area.
\end{abstract}

Keywords: Posyandu utilization, total customer sacrifices, under-five children weighed

\section{PENDAHULUAN}

Keberhasilan pembangunan kesehatan Indonesia tidak terlepas dari partisipasi aktif masyarakat dalam memanfaatkan pelayanan kesehatan. Peranan aktif masyarakat dan swasta dalam penyelenggaran upaya kesehatan masyarakat strata pertama dapat diwujudkan melalui berbagai upaya, yaitu dimulai dari diri sendiri, keluarga sampai dengan upaya kesehatan yang bersumberdaya masyarakat (UKBM), termasuk melalui Pos Pelayanan Terpadu (Posyandu) (Kemenkes RI, 2011). Salah satu dari 5 program prioritas Posyandu adalah perbaikan gizi melalui kegiatan pembinaan gizi masyarakat, di mana cakupan balita ditimbang yang dapat mencerminkan partisipasi ibu balita dalam memanfaatkan Posyandu merupakan salah satu indikator yang dapat digunakan untuk menilai keberhasilan program tersebut (Kemenkes RI, 2014).
Berdasarkan data Dinas Kesehatan Kota Surabaya pada tahun 2012 sampai dengan tahun 2014, salah satu kecamatan yang memiliki angka cakupan balita ditimbang di bawah target yaitu berada pada wilayah kerja Puskesmas Kenjeran Kota Surabaya, yaitu sebesar 74,33 \% (target $75 \%$ pada tahun 2012 ), $68,30 \%$ (target $80 \%$ pada tahun 2013), dan $79,9 \%$ (target $85 \%$ pada tahun 2014). Belum tercapainya target cakupan balita ditimbang tersebut mengindikasikan bahwa partisipasi ibu balita dalam memanfaatkan Posyandu untuk menimbang anak umur 0-59 bulan (balita) dalam upaya pemantauan pertumbuhan masih belum optimal. Hal tersebut merupakan suatu permasalahan yang perlu untuk segera ditangani. Penelitian ini bertujuan untuk menyusun rekomendasi sebagai upaya peningkatan pemanfaatan Posyandu oleh ibu balita yang merupakan customer dari Posyandu bedasarkan 
analisis total customer sacrifices. Hasil penelitian diharapkan dapat menjadi masukan untuk meningkatkan pelayanan Posyandu di wilayah kerja Puskesmas Kenjeran Kota Surabaya sehingga dapat mengurangi pengorbanan yang dikeluarkan oleh customer.

\section{PUSTAKA}

Pos Pelayanan Terpadu (Posyandu)

Pos Pelayanan Terpadu (Posyandu) merupakan perpanjangan tangan puskesmas yang memberikan pelayanan dan pemantauan kesehatan yang dilaksanakan secara terpadu. Posyandu adalah salah satu bentuk upaya kesehatan bersumber daya masyarakat yang dikelola dan diselenggarakan dari, oleh, untuk, dan bersama masyarakat dalam penyelenggaraan pembangunan kesehatan (Iswarawanti, 2010). Posyandu berfungsi sebagai wadah pemberdayaan masyarakat dalam alih informasi dan keterampilan dari petugas kepada masyarakat dan antar sesama masyarakat dalam rangka mempercepat penurunan Angka Kematian Ibu (AKI), Angka Kematian Bayi (AKB), dan Angka Kematian Balita (AKABA), serta sebagai wadah untuk mendekatkan pelayanan kesehatan dasar (Kemenkes RI, 2011).

Pada pelayanan kesehatan berbentuk Upaya Kesehatan Bersumber daya Masyarakat (UKBM) seperti Posyandu yang menawarkan produk pelayanan berupa jasa, di mana produk berupa jasa mempunyai atribut pengalaman dan kepercayaan yang tinggi (Kotler \& Keller, 2009), dan dapat berpengaruh terhadap nilai yang dirasakan serta kepuasan customer (Chen \& Lin, 2014), tingkat pemanfaatan terhadap pelayanan kesehatan tersebut dapat dilihat dari tingkat partisipasi masyarakat. Partisipasi masyarakat dalam pemanfaatan Posyandu adalah keikutsertaan ibu balita pada pelayanan kesehatan balita di Posyandu. Tingkat partisipasi masyarakat terhadap pemanfaatan Posyandu dapat dilihat dari indikator cakupan balita ditimbang yang merupakan salah satu indikator keberhasilan Posyandu dalam usaha perbaikan gizi (Kemenkes RI, 2014).

\section{Total Customer Sacrifices}

Total Customer Sacrifices merupakan bagian dari salah satu atribut customer value, yaitu keseluruhan pengorbanan yang dikeluarkan oleh customer dalam kaitannya dengan penawaran pasar, baik berupa pengorbanan dalam bentuk moneter, waktu, tenaga, maupun psikis (Kotler \& Armstrong, 2001). Nilai pelanggan (customer value) adalah nilai yang dipersepsikan berdasarkan selisih antara total manfaat dan total pengorbanan yang dikeluarkan oleh customer (Kotler \& Keller, 2009). Pengorbanan yang telah dikeluarkan oleh customer untuk mendapatkan barang atau jasa terdiri dari aspek moneter seperti harga (Kotler \& Keller, 2009) dan aspek non moneter seperti waktu, biaya pencarian, dan usaha secara fisik (Pura, 2005) mempunyai pengaruh yang signifikan terhadap kepuasan customer (Krisno \& Samuel, 2013).

Menurut Kotler \& Keller (2003), upaya mengurangi pengorbanan yang dikeluarkan, baik pengorbanan moneter, pengorbanan waktu, pengorbanan tenaga, dan pengorbanan psikis, merupakan salah satu upaya yang dapat dilakukan untuk meningkatkan nilai pelanggan (customer value). Arisandi (2014) menyebutkan bahwa terdapat pengaruh signifikan antara customer value 
terhadap pemanfaatan Posyandu, khususnya pada penimbangan balita. Oleh karena itu, upaya pengurangan pengorbanan tersebut dapat menjadi pilihan untuk meningkatkan nilai dari pemanfaatan Posyandu oleh ibu balita sehingga frekuensi kedatangan ke Posyandu dapat meningkat.

\section{METODE}

Penelitian ini merupakan penelitian kuantitatif dengan jenis penelitian analitik dan menggunakan pendekatan observasional dengan rancang bangun cross sectional. Populasi pada penelitian adalah semua ibu balita (ibu maupun pengasuh bayi usia 0-59 bulan) di wilayah kerja Puskesmas Kenjeran Kota Surabaya. Besar sampel penelitian adalah 112 responden. Responden ini berasal dari salah satu kelurahan dengan cakupan balita ditimbang terendah yang dipilih secara acak menggunakan metode multistage random sampling. Wawancara langsung dengan instrumen penelitian kepada responden yang sebagian besar masih berpendidikan rendah dilakukan dari rumah ke rumah sesuai dengan kesepakatan. Penelitian ini dilakukan selama Maret hingga Mei 2015.

Data primer yang dikumpulkan melalui wawancara ditujukan untuk mengetahui pemanfaatan Posyandu dan penilaian ibu balita terhadap pengorbanan yang dikeluarkan dalam pelayanan penimbangan balita di Posyandu. Data yang telah diperoleh kemudian dilakukan proses cleaning dan coding, serta dikategorikan berdasarkan kriteria yang telah dibuat. Data pemanfaatan Posyandu yang diperoleh dari frekuensi kedatangan responden ke Posyandu dikategorikan berdasarkan persentase jumlah kedatangan responden ke posyandu dibandingkan dengan jumlah kedatangan yang seharusnya. Data tersebut dikategorikan menjadi sangat jarang hingga selalu datang ke Posyandu, yaitu sangat jarang $(<60 \%)$, jarang $(60 \%-<85 \%)$, sering $(85 \%-<100 \%)$, dan selalu (100\%). Sedangkan data penilaian terhadap pengorbanan yang dikeluarkan dikategorikan menjadi sangat kecil hingga sangat besar berdasarkan perhitungan indeks, yaitu sangat kecil $(1,00<x \leq 1,75)$, kecil $(1,75<x \leq 2,5)$, besar $(2,5<x \leq 3,25)$, dan sangat besar $(3,25<x \leq 4)$. Hasil tersebut kemudian dianalisis menggunakan Uji Korelasi Spearman untuk mengetahui ada tidaknya hubungan antara pengorbanan yang dikeluarkan dengan pemanfaatan Posyandu. Analisis hasil dengan menggunakan studi literatur kemudian dijadikan sebagai dasar pertimbangan untuk menyusun rekomendasi untuk meningkatkan pemanfaatan Posyandu oleh ibu balita di Puskesmas Kenjeran Kota Surabaya.

\section{HASIL \& PEMBAHASAN}

Pemanfaatan Posyandu oleh Ibu Balita di Wilayah Kerja Puskesmas Kenjeran Kota Surabaya

Pemanfaatan Posyandu yang merupakan salah satu bentuk upaya kesehatan bersumber daya masyarakat yang dikelola dan diselenggarakan dari, oleh, untuk, dan bersama masyarakat (Iswarawanti, 2010) di wilayah kerja Puskesmas Kenjeran Kota Surabaya ditunjukkan dari frekuensi kedatangan responden ke Posyandu untuk memanfaatkan pelayanan penimbangan balita. Hasil penelitian menunjukkan bahwa mayoritas responden sebesar $32,1 \%$ jarang datang ke Posyandu, artinya kedatangan responden ke Posyandu masih kurang 
dari $60 \%$ kedatangan yang seharusnya. Hal ini menunjukkan bahwa pemanfaatan Posyandu di wilayah kerja Puskesmas Kenjeran Kota Surabaya masih tergolong rendah. Karakteristik responden yang mayoritas bekerja sebagai ibu rumah tangga yang membantu suaminya mengolah hasil tangkapan ikan maupun kerang menjadi alasan responden untuk jarang datang ke Posyandu guna memanfaatkan jasa pelayanan penimbangan balita.

Karakteristik pembeli atau pengguna produk baik barang maupun jasa menjadi salah satu aspek yang turut memberikan pengaruh terhadap persepsi dan reaksinya atas produk yang dikonsumsi (Kotler \& Armstrong, 2001). Produk berupa jasa penimbangan balita di Posyandu yang mempunyai atribut pengalaman dan kepercayaan yang tinggi juga dapat berpengaruh terhadap nilai yang dirasakan dan kepuasan customer ketika memanfaatkannya (Chen \& Lin, 2014). Adanya pengalaman kurang menyenangkan yang didapatkan responden ketika mengonsumsi jasa pelayanan penimbangan balita di Posyandu cenderung dapat mempengaruhi penilaiannya terhadap besar pengorbanan yang dikeluarkan. Pengalaman tersebut dapat berupa adanya rasa ketidakyamanan yang didapatkan responden, salah satunya karena ruangan Posyandu di wilayah kerja Puskesmas Kenjeran Kota Surabaya yang sempit dan panas sehingga cenderung membuat balita rewel dan menangis, serta susah dibujuk untuk ditimbang. Kotler \& Keller (2009) menyatakan bahwa melalui pengalaman dan pembelajaran masyarakat akan mendapatkan keyakinan dan sikap yang selanjutnya dapat mempengaruhi perilaku pembelian atau konsumsi atas suatu produk.

\section{Analisis Total Customer Sacrifices}

Pengorbanan yang dikeluarkan oleh customer dikelompokkan menjadi empat jenis yaitu pengorbanan moneter, pengorbanan waktu, pengorbanan tenaga, dan pengorbanan psikis. Hasil penelitian mengenai penilaian customer terhadap keseluruhan pengorbanan yang dikeluarkan dapat ditampilkan pada Tabel 1.

Berdasarkan Tabel 1 dapat diketahui bahwa total customer sacrifices yang dikeluarkan oleh responden dalam pelayanan penimbangan balita di Posyandu wilayah kerja Puskesmas Kenjeran Kota Surabaya termasuk dalam kategori sangat kecil $(1,48)$. Dari keempat jenis pengorbanan, pengorbanan moneter dan pengorbanan psikis sudah dirasakan sangat kecil oleh responden. Pengorbanan waktu dan pengorbanan tenaga juga sudah dirasakan kecil, namun pada beberapa indikator masih ada yang dinilai besar oleh customer, yaitu pada indikator kedua dan ketiga terkait waktu dan tenaga yang dikeluarkan untuk menunggu antrian penimbangan balita dan serangkaian proses pelayanan. Pengorbanan yang telah dikeluarkan oleh customer untuk mendapatkan barang atau jasa mempunyai pengaruh yang signifikan terhadap kepuasan customer dalam memanfaatkan barang atau jasa tersebut (Krisno \& Samuel, 2013).

Pengorbanan moneter berkaitan dengan biaya finansial yang dikeluarkan oleh customer dalam memanfaatkan pelayanan penimbangan balita di Posyandu. Pengorbanan biaya yang dikeluarkan untuk mendapatkan pelayanan penimbangan balita di Posyandu termasuk biaya 
Tabel 1 Penilaian terhadap Customer Sacrifices dalam Pelayanan Penimbangan Balita di Posyandu Wilayah Kerja Puskesmas Kenjeran Kota Surabaya

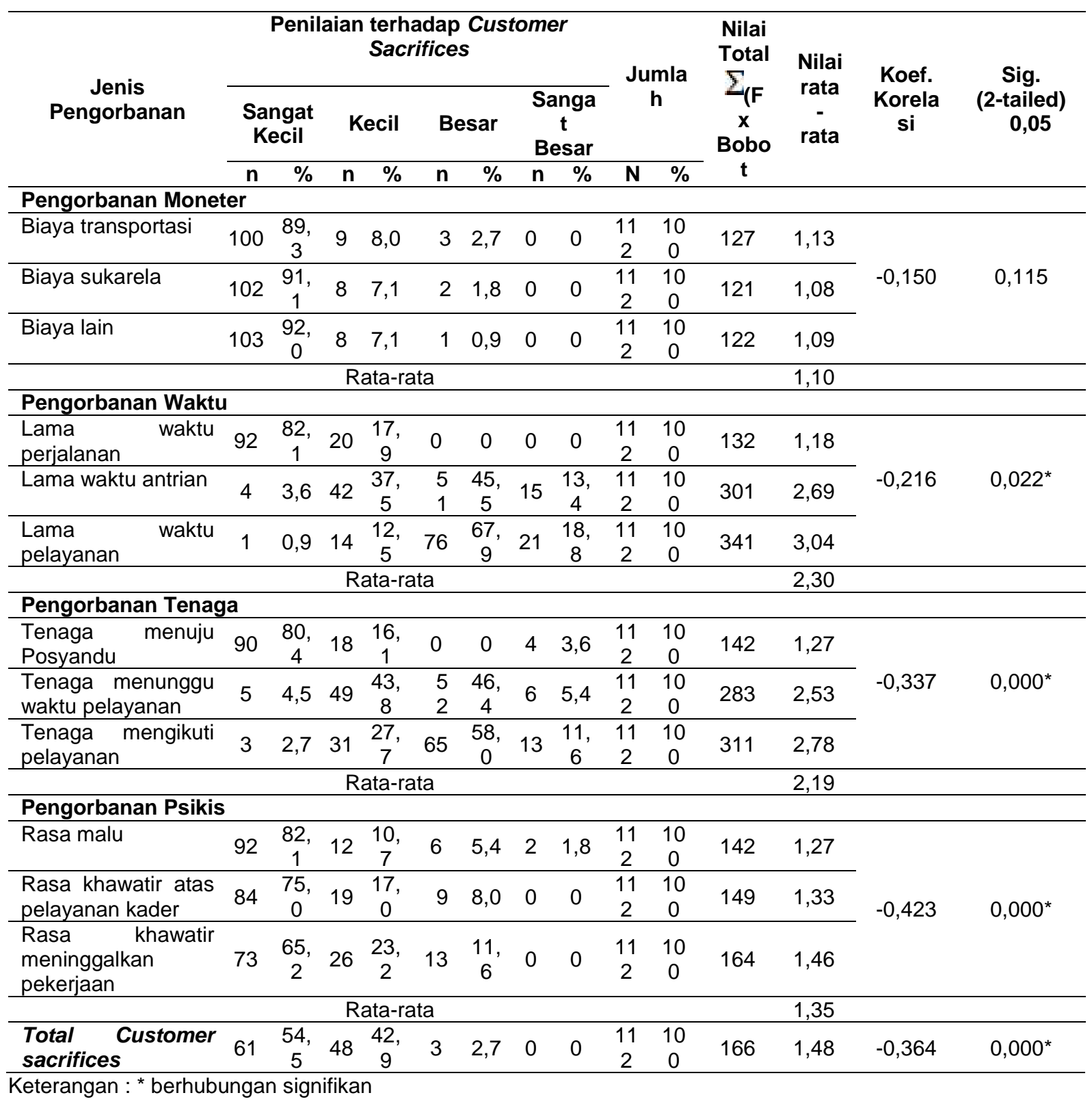

perjalanan menuju Posyandu sudah dinilai sangat kecil. Hal tersebut dikarenakan lokasi Posyandu yang mudah dijangkau dan sifat Posyandu yang tidak boleh melakukan penarikan uang yang dapat membebankan pengunjung Posyandu. Sumber dana untuk pembiayaan dalam penyelenggaraan Posyandu di wilayah kerja Puskesmas Kenjeran Kota Surabaya berasal dari
APBD Kota Surabaya, iuran masyarakat secara sukarela, dan sumber dana lainnya.

Hasil penelitian menunjukkan tidak ada hubungan yang signifikan antara penilaian responden terhadap keseluruhan pengorbanan moneter dengan frekuensi kedatangan responden untuk memanfaatkan pelayanan penimbangan balita di Posyandu. Meskipun responden telah merasakan keseluruhan pengorbanan moneter yang kecil, 
namun hal tersebut tidak menjadi alasan responden untuk lebih cenderung memanfaatkan pelayanan penimbangan balita di Posyandu. Hal tersebut menunjukkan bahwa faktor pengorbanan moneter tidak begitu dianggap penting dan ada faktor selain besar atau kecil pengorbanan moneter yang dikeluarkan oleh responden yang menjadikan pemanfaatan pelayanan tersebut masih rendah, misalnya terlalu besarnya biaya atas waktu yang dikeluarkan, biaya fisik (kelelahan dan ketidaknyamanan), maupun biaya psikis (kekhawatiran dan ketakutan) seperti yang diungkapkan Lovelock \& Wright (2007).

Pengorbanan waktu melekat pada penyerahan produk jasa yang menyangkut waktu yang dihabiskan oleh customer dalam seluruh aspek proses penyerahan produk jasa tersebut (Lovelock \& Wright, 2007). Menurut Ayuningtyas \& Aeni (2011), lama waktu yang dikorbankan sampai mendapatkan pelayanan dapat digunakan untuk mengetahui seberapa besar pengorbanan customer dalam mendapatkan pelayanan kesehatan yang dibutuhkan. Hasil penelitian menunjukkan bahwa mayoritas sebanyak 51 responden (45,5\%) menilai bahwa waktu yang dikeluarkan untuk menunggu antrian penimbangan balita termasuk besar, karena kadangkala responden harus menunggu hingga sekitar 30 menit. Waktu selama proses pelayanan yang lama, yaitu maksimal sekitar 30-60 menit juga membuat 76 responden $(67,9 \%)$ merasakan pengorbanan yang besar untuk menunggu.

Jumlah balita yang banyak dengan kapasitas tempat yang terbatas dan waktu pelayanan yang sama memicu terjadinya antrian yang cukup lama, yaitu maksimal 60 menit. Menurut Panduan Tenaga Pelaksana Gizi Puskesmas dalam Pembinaan Kader Posyandu (Kemenkes RI, 2012), jumlah balita dalam satu Posyandu yang ideal adalah 50-80 balita (kurang dari 100 balita). Sedangkan jumlah balita di Posyandu wilayah kerja Puskesmas Kenjeran Kota Surabaya mencapai 100150 balita dalam satu Posyandu. Adanya hubungan yang signifikan diantara keduanya menunjukkan bahwa semakin besar pengorbanan waktu yang dirasakan responden maka akan memberikan kecenderungan responden untuk kurang memanfaatkan Posyandu. Responden yang masih merasakan pengorbanan waktu yang besar untuk menunggu waktu antrian penimbangan balita dan proses pelayanan cenderung lebih rendah frekuensi kedatangannya ke Posyandu.

Tenaga yang paling besar dikeluarkan oleh mayoritas sebanyak 65 responden $(58,0 \%)$ adalah tenaga untuk mengikuti serangkaian pelayanan yang ada di Posyandu, diikuti oleh tenaga yang dikeluarkan untuk menunggu waktu pelayanan yang juga dinilai besar oleh 52 responden (46,4\%). Balita yang rewel dan susah dibujuk untuk ditimbang serta proses pelayanan yang lama karena antri dan adanya rasa kurang nyaman akibat ruangan yang panas membuat pengorbanan yang dirasakan besar. Hasil penelitian juga menunjukkan adanya hubungan yang signifikan antara penilaian terhadap keseluruhan pengorbanan tenaga dengan pemanfaatan Posyandu, sehingga apabila responden menilai pengorbanan tenaga yang dikeluarkan besar maka responden akan cenderung kurang memanfaatkan dan jarang datang ke 
Posyandu. Menurut Kotler \& Keller (2009), tenaga yang dikeluarkan oleh seseorang untuk mendapatkan suatu produk sangat mempengaruhi persepsi dalam keputusan pembelian. Dengan demikian dapat diketahui bahwa adanya pengorbanan yang dirasakan sangat besar tersebut dapat membuat frekuensi kedatangan ke Posyandu menjadi cenderung berkurang. Bagi sebagian orang tenaga tersebut dianggap tidak terlalu penting, namun bagi sebagian orang lainnya tenaga yang dikorbankan untuk mendapatkan suatu produk jasa merupakan suatu aspek perlu diperhatikan (Kotler \& Andreasen, 1995).

Menurut Kotler \& Keller (2009), faktor psikis turut berpengaruh terhadap pengambilan keputusan seseorang untuk melakukan pembelian suatu produk. Kecenderungan responden untuk memanfaatkan Posyandu berhubungan secara signifikan dengan penilaian responden terhadap keseluruhan pengorbanan psikis yang dikeluarkan. Pengorbanan psikis yang dikeluarkan oleh responden rata-rata termasuk dalam kategori sangat kecil. Pengorbanan paling besar yang dikeluarkan oleh responden adalah terkait kekhawatiran meninggalkan aktivitas pekerjaannya untuk datang menimbang balita ke Posyandu. Meskipun sebagian besar responden adalah ibu rumah tangga, namun karena sebagian besar pekerjaan suami adalah sebagai nelayan ikan maupun kerang sehingga responden juga turut membantu pekerjaan suaminya tersebut.

Responden yang merasakan pengorbanan psikis atas adanya rasa malu cenderung sangat jarang ke Posyandu. Selain itu pelayanan penimbangan balita di Posyandu yang dilakukan oleh kader Posyandu membuat sebagian responden merasa khawatir oleh karena anggapan bahwa kader Posyandu adalah orang biasa yang kurang mempunyai keahlian maupun pengetahuan yang cukup mengenai kesehatan. Kekhawatiran tersebut lebih dirasakan oleh responden yang sangat jarang dan jarang ke Posyandu untuk menimbang balitanya. Oleh karena itu, kekhawatiran menjadi salah satu dari pengorbanan psikis yang melekat pada produk jasa karena berkaitan dengan atribut kepercayaan dan pengalaman. Pengorbanan psikis tersebut merupakan keadaan emosi tidak diinginkan yang dialami customer sebagai akibat dari proses penyerahan jasa. Selain itu, pada produk jasa yang mempunyai atribut kepercayaan dan pengalaman tinggi juga dapat menciptakan pengorbanan psikis yang lebih tinggi, salah satunya adalah rasa khawatir (Lovelock \& Wright, 2007).

Secara keseluruhan, penilaian terhadap total customer sacrifices menunjukkan hasil bahwa pengorbanan yang dikeluarkan oleh customer termasuk sangat kecil. Sebagian besar responden sudah merasakan keseluruhan pengorbanan yang sangat kecil, dan semakin kecil keseluruhan pengorbanan yang dikeluarkan oleh responden cenderung membuat pemanfaatan Posyandu semakin tinggi, dikarenakan keduanya mempunyai hubungan signifikan yang berlawanan arah. Arisandi (2014) juga menyatakan bahwa terdapat hubungan dan pengaruh yang signifikan antara total customer sacrifices dengan pemanfaatan Posyandu. Akan tetapi, adanya waktu yang dikeluarkan oleh customer untuk menunggu lamanya antrian dan 
serangkaian proses pelayanan masih dirasakan besar sehingga cenderung membuat customer berfikir kembali untuk memutuskan akan memanfaatkan kembali pelayanan penimbangan balita di Posyandu atau tidak, dan hasil penelitian menunjukkan bahwa mayoritas customer memilih jarang memanfaatkan pelayanan tersebut.

\section{Rekomendasi Peningkatan Pemanfaatan Posyandu Berdasarkan Analisis Total Customer Sacrifices}

Upaya peningkatan pemanfaatan Posyandu di wilayah kerja Puskesmas Kenjeran Kota Surabaya sebaiknya mengurangi pengorbanan yang dikeluarkan customer berdasarkan salah satu upaya yang dikemukakan oleh Kotler \& Keller (2003) sebagai bagian dari upaya peningkatan customer value. Pada aspek pengorbanan waktu, pengorbanan tenaga, dan pengorbanan psikis menunjukkan adanya hubungan signifikan dengan pemanfaatan Posyandu dapat diberikan prioritas untuk lebih dipertimbangkan. Aspek tersebut dianggap penting dan menjadi alasan customer memanfaatkan pelayanan penimbangan balita di Posyandu.

Rekomendasi untuk meningkatkan pemanfaatan Posyandu di wilayah kerja Puskesmas Kenjeran Kota Surabaya antara lain yaitu dengan menjadikan kecilnya pengorbanan moneter sebagai seruan yang perlu ditonjolkan ketika mengadakan sosialisasi dan upaya penyadaran mengenai pentingnya melakukan penimbangan balita di Posyandu. Penyuluhan intensif mengenai pentingnya imunisasi juga perlu diberikan, mengingat masih ada anggapan masyarakat yang perlu diluruskan, seperti dampak pemberian imunisasi yang justru dianggap menyebabkan balita panas dan sakit. Adanya anggapan tersebut cenderung membuat ibu balita enggan untuk ke Posyandu. Mulai tahun 2015, Pemerintah Kota Surabaya telah menetapkan bahwa Posyandu mempunyai dua hari buka dengan kegiatan penimbangan balita dan Pemberian Makanan Tambahan (PMT) penyuluhan pada hari pertama, sedangkan pada hari kedua dikhususkan untuk kegiatan Pemberian Makanan Tambahan (PMT) penyuluhan saja sebagai upaya untuk menjaring sasaran Posyandu dan meningkatkan pengetahuan ibu balita. Oleh karena itu, kader Posyandu turut memegang peranan penting dalam memberikan penyuluhan kesehatan, baik penyuluhan mengenai pentingnya imunisasi dan pemantauan pertumbuhan anak setiap bulannya di Posyandu, maupun penyuluhan lainnya yang diperlukan oleh ibu balita.

Kecepatan serangkaian proses pelayanan yang dilakukan oleh kader Posyandu perlu ditingkatkan, termasuk proses pencatatan hasil penimbangan ke dalam Kartu Menuju Sehat (KMS), karena ibu balita merasakan proses tersebut yang dinilai lama sehingga membuat antrian panjang. Banyak dan tercukupinya jumlah kader di masingmasing meja pelayanan dapat optimal apabila terdapat pembagian tugas yang baik sesuai dengan kemampuan yang dimiliki. Kader Posyandu merupakan anggota masyarakat yang bersedia, mampu, dan memiliki waktu untuk menyelenggarakan kegiatan Posyandu secara sukarela (Kemenkes RI, 2011), sehingga keberadaanya perlu selalu diberikan apresiasi dan 
pelatihan untuk menambah pengetahuan serta memampukan dalam menjalankan tugas dan tanggung jawabnya.

Proses kedatangan ibu balita perlu diatur sedemikian rupa untuk meminimalisir terjadinya waktu proses pelayanan yang lama sehingga menjadikan antrian panjang. Jumlah balita yang banyak di satu RW yang dilayani pada satu Posyandu dapat diatasi dengan membaginya menjadi kelompok-kelompok berdasarkan kelompok RT apabila mendukung. Pemekaran Posyandu dapat dilakukan apabila terdapat sarana prasarana dan sumber daya manusia yang memadai, sehingga dukungan dari berbagai pelaksana Posyandu, termasuk pihak kecamatan serta tokoh masyarakat lainnya tentu sangat diperlukan.

Keramahan serta keterampilan kader dalam memberikan pelayanan perlu senantiasa ditingkatkan, sehingga dapat mengatasi dan meminimalisir balita yang rewel dan menangis. Kader Posyandu bersama dengan pelaksana Posyandu lainnya juga perlu mendesain tempat maupun proses pelayanan yang dapat membuat balita merasa nyaman serta dapat ditunjang dengan adanya koordinasi dan kerjasama dengan pihak penyedia alat permainan edukatif. Adanya sarana prasarana yang lengkap dan memadai serta mempunyai standar yang sama antar Posyandu tentunya dapat menunjang proses pemberian layanan yang ada di Posyandu dan dapat menarik ibu balita untuk menimbangkan balitanya ke Posyandu.

Kekhawatiran ibu balita untuk melakukan penimbangan balita di Posyandu karena dilakukan oleh kader dan kekhawatiran karena harus meninggalkan pekerjaannya dapat diminimalisir dengan adanya penjelasan dari petugas puskesmas dan tokoh masyarakat setempat bahwa kader yang melayani balitanya adalah kader terlatih yang telah mendapatkan pelatihan berkala dari pihak puskesmas. Pengetahuan kepada ibu mengenai manfaat yang diterima ketika melakukan penimbangan balita di Posyandu juga perlu diberikan agar ibu tidak risau meskipun harus meninggalkan pekerjaan atau aktivitasnya sejenak karena semua ditujukan untuk kesehatan balita dan demi pertumbuhan balitanya kelak.

\section{SIMPULAN}

Berdasarkan hasil penelitian, dapat disimpulkan bahwa meskipun total customer sacrifice sudah dinilai sangat kecil oleh responden, namun masih besarnya waktu yang dikorbankan untuk menunggu antrian penimbangan balita dan serangkaian proses pelayanan membuat responden jarang datang memanfaatkan Posyandu untuk melakukan penimbangan balita. Oleh karena itu, upaya peningkatan pemanfaatan Posyandu yang dapat direkomendasikan adalah dengan dengan meningkatkan kecepatan proses pelayanan dan keterampilan kader Posyandu, mengatur proses kedatangan ibu balita untuk meminimalisir lama waktu antrian, dan melakukan pemekaran Posyandu apabila sumber daya mendukung.

Penelitian ini hanya terbatas pada pengkajian masalah berdasarkan persepsi customer terhadap pengorbanan yang dirasakan, dan terbukti bahwa terdapat hubungan yang signifikan antara 
total customer sacrifice dengan pemanfaatan

Posyandu. Untuk penelitian selanjutnya dapat

dilakukan uji pengaruh untuk mengetahui seberapa

besar pengaruh diantara keduanya dan pengkajian

masalah dapat dilakukan berdasarkan faktor lain

seperti faktor Posyandu, sehingga dapat diketahui

penyebab utama yang berpengaruh terhadap

rendahnya pemanfaatan Posyandu.

\section{DAFTAR PUSTAKA}

Arisandi, N. D. (2014). Pengaruh Customer Value Terhadap Penimbangan Balita di Posyandu Wilayah Puskesmas Gedangan Kabupaten Sidoarjo. Skripsi. Surabaya: Universitas Airlangga.

Ayuningtyas, D. \& Aeni, N. (2011). Analisis Nilai Pelanggan pada Pasien Polionkologi RS Kanker $X$ dan Pelayanan Penyakit Kanker Terpadu SRUP Y Tahun 2010. Jurnal manajemen pelayanan Kesehatan, 14, 108113.

Chen, S.-C \& Lin, C.-P. (2014). The Impact of Customer Experience and Perceived Value on Sustainable Social Relationship in Blogs: An empirical study Technological Forecasting \& Social Change, 1-11.

Dinkes Kota Surabaya. (2013). Profil Kesehatan Dinas Kesehatan Kota Surabaya Tahun 2012. Surabaya.
Dinkes Kota Surabaya. (2014). Profil Kesehatan Dinas Kesehatan Kota Surabaya Tahun 2013. Surabaya.

Dinkes Kota Surabaya. (2015). Profil Kesehatan Dinas Kesehatan Kota Surabaya Tahun 2014. Surabaya.

Iswarawanti. (2010). Kader Posyandu: Peranan dan Tantangan Pemberdayaanya dalam Usaha Peningkatan Gizi Anak di Indonesia. Jurnal Manajemen Pelayanan Kesehatan, 13, 169173.

Kemenkes RI. (2011). Pedoman Umum Pengelolaan Posyandu. Jakarta.

Kemenkes RI. (2012). Panduan tenaga Pelaksana Gizi Puskesmas Dalam Pembinaan Kader Posyandu. Jakarta

Kemenkes RI. (2014). Laporan Akuntabilitas Kinerja Ditjen Bina Gizi \& KIA tahun 2013. Jakarta.

Krisno \& Samuel. (2013). Pengaruh Perceived Quality, Perceived Sacrifice dan Perceived Value terhadap Customer Satisfaction di Informa Innovative Furnishing Pakuwon City Surabaya. Jurnal Manajemen Pemasaran Petra, 1, 1-12.

Kotler,P. \& Andreasen,A.R. (1995). Strategi Pemasaran untuk Organisasi Nirlaba. Jakarta: CV. Intermedia

Kotler,P. \& Armstrong,G. (2001). Prinsip-prinsip Pemasaran, Edisi Kedelapan, Jilid 2. Yogyakarya: Gadjah mada University Press.

Kotler,P. \& Keller,K.L. (2003). Marketing Management. 12th Edition. New Jersey: Pearson Prentice Hall.

Kotler,P. \& Keller,K. (2009). Manajemen Pemasaran, Edisi Ketigabelas, Jilid I. Jakarta: Erlangga.

Lovelock,C.H \& Wright,L.K. (2007). Manajemen Pemasaran jasa. Jakarta: PT. Indeks.

Pura, M. (2005). Linking Perceived Value and Loyalty in Location based Mobile Services. Managing Service Quality ,15, 509-538. 